\title{
Agama dalam Pusaran Konflik \\ (Studi Analisis Resolusi Terhadap Munculnya Kekerasan Sosial Berbasis \\ Agama di Indonesia)
}

\author{
Buyung Syukron \\ IAIN Metro \\ buyungsyukron@gmail.com
}

\begin{abstract}
Abstrak
Tidak bisa dipungkiri, bahwa Isu kekerasan atas nama agama adalah fenomena transnasional yang ibarat dua sisi mata uang berpotensi menciptakan harmoni dan konflik. Dan ketika sentimen (ghirah) sudah terkooptasi dan menjadi stigma dengan mengatasnamakan kebenaran dan agama, maka atas dasar itu semua, fungsi Tuhan digunakan untuk alat pembenaran kejahatan, kekerasan, ancaman dan balas dendam. Proyeksi manusia, di satu sisi seolah-olah kekerasan Tuhan tampil sebagai bagian dan kesucian-Nya sehingga kekerasan Tuhan menjadi paling benar dan tampil sebagai alat utama penegakan keadilan. Di sisi lain kekerasan atas nama Tuhan disamakan dalam bentuk pembebasan dalam rangka mengajak ke pertobatan. Padahal kalau kita mau sedikit berfikir secara komprehensif dan terintegratif, perbedaan dalam bentuk pemahaman keagamaan bisa juga menjadi kekuatan membangun kebersamaan guna mencapai tujuan keutuhan serta kemajuan umat manusia. Sayangnya, kekuatan itu (pada banyak kasus) hanya difungsikan untuk merusak serta penyingkiran terhadap orang lain; ha-hal tersebut sangat mudah digunakan oleh para pemimpin serta tokoh masyarakat, agama, politik, dalam rangka mencapai tujuan tertentu. Dengan itu, agaknya, sentimen (ghirah) keagamaan bisa dijadikan kendaraan yang paling ideal untuk mencapai tujuan dimaksud.

Kata Kunci: Agama dan Kekerasan, Kekerasan Sosial, Kekerasan berbasis Agama, Toleransi dan Intoleransi Keberagamaan
\end{abstract}

\section{Pendahuluan}

Menyeruaknya konflik bernuansa agama yang terjadi di negeri ini mengundang keprihatinan berbagai pihak, termasuk diantaranya adalah pemerintah. Munculnya konflik seperti itu bertolak belakang dengan kesan masyarakat dunia yang melihat Indonesia sebagai contoh bangsa yang menjunjung tinggi toleransi beragama. Kenyataannya memang demikian, bahwa selama sejarah bangsa ini berdiri belum pernah muncul konflik bernuansa agama yang semasif belakangan. Karena itu muncul wacana untuk mencegahnya dengan berbagai pendekatan.

Harus diakui bahwa Indonesia dikenal sebagai negara yang majemuk (plural) dalam hal agama dan keyakinan. Kemajemukan ini mengandung dua potensi yang positif dan negatif sekaligus. Potensi kemajemukan bermakna positif karena ragam keyakinan merupakan sumber nilai dan local wisdom bagi keutuhan bangsa ini. Keragaman keyakinan warganya menjadi perekat dan pengokoh bangunan Negara ini. Keragaman agama yang dipeluk warga menjadi faktor integratif bagi Indonesia. Pada sisi lain, keragaman agama seperti ini dapat menjadi faktor disintegrasi bangsa karena konflik-konflik yang timbul karenanya. 
Preposisi tentang Indonesia sebagai negara yang mayoritas penduduknya beragama Islam sudah tidak dapat terbantahkan lagi. Namun, selain Islam, ada lima agama lain yang diakui sebagai agama nasional yaitu : Kristen Katolik, Kristen Protestan, Hindu, Budha, dan Konghucu. Penduduk muslim kebanyakannya berada di Pulau Jawa dan Sumatera (wilayah barat di Indonesia), sedangkan agama lainnya tersebar tersebar di seluruh wilayah Indonesia. Menurut hasil sensus tahun 2010 , 87,18 \% dari 237.641 .326 penduduk Indonesia adalah Muslim, 6,96 \% beragama Kristen Protestan, 2,9\% beragama Kristen Katolik, 1,69\% memeluk agama Hindu, 0,72\% beragama Buddha, 0,05\% beragama Konghucu, 0,13\% agama lainnya, dan 0,38\% tidak diketahui jelas. ${ }^{1}$

Dalam term Karen Amstrong menjelaskan pengertian agresi membagi menjadi dua bentuk, yaitu agresi keluar dan agresi kedalam. Agresi keluar adalah ledakan-ledakan emosi dan kemarahan hebat meluap-luap dalam bentuk tindakan sewenang-wenang, peyerangan, penyergapan, serbuan, kekejaman, perbuatan-perbuatan yang menimbulkan penderitaan dan kesakitan, pengrusakan orang lain, tindakan permusuhan ditujukan kepada seseorang atau benda. ${ }^{2}$ Sedangkan agresi kedalam terjadi ketika saluran untuk pelontaran agresi keluar terhambat sama sekali, melalui pendesakan dan bunuh diri.

Tidak berlebihan apabila dalam beberapa perdebatan antara agama dan kekerasan, pada akhirnya memunculkan kesimpulan bahwa: perbedaan teologis maupun praktek ritual itu menjadi bagian dari "theological discourse" yang memang akan abadi. Hingga akhir zaman akan ada yang menerima tauhid dan masih akan banyak yang tidak menerima. Dalam perspektif agama Islam, Allah menegaskan: "ilaallahi marji'ukum fayinnabiukum bimaa kuntum ta'malun". Intinya, keyakinan seseorang biarlah menjadi tanggung jawabnya masing-masing di akhirat kelak. Bahkan konsep dakwah dalam Islam tidak pernah bertujuan mengislamkan seseorang. Karena toh juga secara teologis dan keyakinan Islam, yang bisa memberikan hidayah itu hanya DIA yang mencipta langit dan bumi.

\section{Pembahasan}

\section{Teori-Teori Kekerasan Sosial}

Beberapa teori yang berkembang terhadap konflik kekerasan sosial yang berkembang di Indonesia, kekerasan sosial dalam wilayah agama

\footnotetext{
1 Tim Penyusun, Lampu Merah Kebebasan Beragama: Laporan Kebebasan Beragama dan Toleransi di Indonesia, (Jakarta: the Wahid Institute, 2011).

2 Di dalam buku ini, pengarang mencatatkan berbagai kasus kekerasan berbasis agama yang terjadi di seluruh dunia dan pelakunya adalah penganut berbagai agama. Di kancah internasional, beberapa kasus kekerasan berbasis agama di Indonesia sangat mempengaruhi persepsi orangorang asing terhadap Muslim Indonesia. Sebut saja Amrozi, Abu Bakar Ba'syir, seluruh dunia pasti pernah mendengar nama mereka berdua. Dimulai dari menyebutkan beberapa fenomena kekerasan yang mennggemparkan dunia, dilanjutkan dengan faktor-faktor, legitimasi agama, eskalasi intensitas terjadinya kekerasan agama, dan lain-lain. Lihat Karen Amstrong, Berperang Demi Tuhan: Fundamentalisme Dalam Islam, Kristen, dan Yahudi, (Bandung: Mizan, 2001), h. 76-77
} 
memperoleh perhatian serius. Hal ini karena kekerasan sosial pada wilayah agama seringkali terjadi baik dengan eskalasi konflik yang luas maupun terbatas.

Menurut Thomas Santoso, teori kekerasan dapat dikelompokkan ke dalam tiga kelompok besar, yaitu sebagai berikut.

a. Teori Kekerasan sebagai Tindakan aktor (individu) atau Kelompok

Para ahli teori kekerasan kolektif ini berpendapat bahwa manusia melakukan kekerasan karena adanya faktor bawaan, seperti kelainan genetik atau fisiologis. Wujud kekerasan yang dilakukan oleh individu dapat berupa pemukulan, penganiayaan ataupun kekerasan verbal berupa kata-kata kasar yang merendahkan martabat seseorang. Sedangkan kekerasan kolektif merupakan kekerasan yang dilakukan oleh beberapa orang atau sekelompok orang.

\section{b. Teori Kekerasan Struktural}

Menurut teori ini kekerasan struktural bukan berasal dari orang tertentu, melainkan terbentuk dalam suatu sistem sosial. Para ahli teori ini memandang kekerasan tidak hanya dilakukan oleh aktor (individu) atau kelompok semata, tetapi juga dipengaruhi oleh suatu struktur, seperti aparatur negara.

c. Teori Kekerasan sebagai Kaitan antara Aktor dan Struktur

Menurut pendapat para ahli teori ini, konflik merupakan sesutu yang telah ditentukan sehingga bersifat endemik bagi kehidupan masyarakat. ${ }^{3}$

Memperkuat teori yang dikemukakan di atas, menurut kajian Wahid Institute ${ }^{4}$, perkembangan konflik biasanya melewati tiga tahapan, yaitu: latent tension, nascent conflict, dan intensified conflict. Pada tahapan pertama, latent tension, konflik masih dalam bentuk kesalahpahaman antara satu dengan lainnya, tetapi antara pihak yang bertentangan belum melibatkan dalam konflik. Tahapan ini bisa disebut juga dengan konflik autistik. Pada tahapan kedua, nescent conflict, konflik mulai nampak dalam bentuk pertentangan meskipun belum menyertakan ungkapanungkapan ideologis dan pemetaan terhadap pihak lawan secara terorganisasi. Sedangkan pada tahapan ketiga, intensified conflict, konflik berkembang dalam bentuk yang terbuka disertai dengan radikalisasi gerakan di antara pihak yang saling bertentangan, dan masuknya pihak

3 Robert N. Bellah, Beyond Belief: Esei-esei Tentang Agama di Dunia Modern, (Jakarta: Paramadina, 2000), h. 40

4 Tim Penyusun, Laporan Kebebasan Beragama/ Berkeyakinan dan toleransi, (Jakarta: the Wahid Institute, 2010), h. 17 
ketiga ke dalam arena kekerasan sosial. Kajian dari Bromley ${ }^{5}$ bisa digunakan sebagai kerangka teoritik dalam mencermati konflik kekerasan sosial yang berbasis agama, karena konflik berbasis agama biasanya terjadi dalam eskalasi yang luas serta ditunjukkan dengan pelibatan pihak lain sebagai pelaku tindak kekerasan sosial dimaksud. Tetapi karena agama selalu berdialektika dengan kehidupan sosial, maka munculnya paradoks dengan dimensi normatif-teologis agama selalu terjadi. Konflik dan aksi kekerasan dalam wilayah agama merupakan salah satu paradoks yang dimaksud.

\section{Agama, Konflik, dan Integrasi Sosial}

Definisi klasik mengenai konflik sebagaimana dikemukakan Louis Coser, adalah: "a struggle over values and claims to secure status, power, and resources, a struggle in which the main aims of opponents are to neutralize, injure, or eliminate rivals". Berdasarkan sejumlah studi misalnya Laporan Penelitian Pola-pola Konflik Keagamaan di Indonesia (1990-2008) yang dilaksanakan Yayasan Wakaf Paramadina bekerjasama dengan Program Magister Perdamaian dan Resolusi Konflik, Universitas Gadjah Mada (MPRKUGM), dan The Asia Foundation (TAF), definisi ini dianggap masih terlalu umum dan tampaknya lebih didasari atas rasionalitas tindakan dengan motif ekonomi-politik. ${ }^{6}$

Hal tersebut mungkin memperlihatkan salah satu kelemahan dalam berbagai penjelasan tentang fenomena konflik, termasuk konflik etniskeagamaan yang menjadi wilayah studi itu. Seperti dikatakan Jacques Bertrand, "In general, theories of ethnic conflict have been poor at differentiating between forms of conflict and better at developing theoretical propositions about the causes of all forms of ethnic conflict". ${ }^{7}$ Dalam konteks yang lebih umum, pernyataan Bertrand itu dapat dipahami sebagai mengindikasikan bahwa banyak penjelasan tentang konflik, termasuk konflik etnis- keagamaan,

${ }_{5}$ Mengapa hal ini bisa terjadi? Jawaban terhadap pertanyaan ini tidak tunggal karena tergantung pada perspektif yang digunakan ketika menganalisis konflik dan kekerasan. Dikatakan oleh Harold Isaacs (1975): “Basic group identity concists of the ready-made set of endowment and identifications that every individual shares with others from the moment of birth by the chance of the family into which he is born". Konflik, menurut pandangan ini, disebabkan oleh perbedaan suku dan karakteristik agama yang merupakan sumber prasangka dan stereotip terhadap kelompok lainnya. Lihat Michael E, Brown, et. al., (eds), The Causes., h. 23

6 Bertrand, Jacques, Nationalism and Ethnic Conflict in Indonesia, (Cambridge: Cambridge University Press, 2004), h. 34. Seperti yang telah ditunjukkan oleh beberapa studi aksi keagamaan, termasuk dalam konteks konflik dan kekerasan sosial sulit untuk dipahami semata-mata dari segi rasionalitas ekonomi dan politik atau kekuasaan. Berbagai tindakan protes atau kekerasan terkait konflik keagamaan banyak berasal dari sumber-sumber kultural dan ideologis agama itu sendiri, dan rasionalitas yang mendasari konflik tersebut lebih bersifat ekspresif atau simbolik; misalnya, sebagai ekspresi dari apa yang dipahami suatu komunitas agama sebagai "ketaatan" terhadap ajaran agama atau sebagai simbol solidaritas terhadap komunitas.

7 Ibid., h. 56 
yang tidak memberi perhatian pada variasi atau kekhasan bentuk-bentuk konflik tersebut.

Dengan menekankan pada kekhasan dari berbagai bentuk konflik keagamaan atau konflik bernuansa agama, kita dimungkinkan untuk menjelaskan mengapa suatu bentuk konflik keagamaan muncul pada waktu dan lokasi tertentu, sementara bentuk lainnya terjadi pada waktu dan tempat yang lain. Penulis sependapat dengan penelitian Tim Paramadina yang berpijak pada asumsi bahwa konflik keagamaan perlu dibedakan berdasarkan jenis isu keagamaan yang menjadi sumber pertikaian. Karena itu, dalam tulisan ini, "konflik keagamaan" atau "konflik bernuansa agama" diartikan sebagai "perseteruan menyangkut nilai, klaim dan identitas yang melibatkan isu-isu keagamaan atau isuisu yang dibingkai dalam slogan atau ungkapan keagamaan". ${ }^{8}$

Agama sebagai sebuah kesadaran makna dan legitimasi tindakan bagi pemeluknya dalam interaksi sosialnya justru mengalami konflik interpretasi, sehingga disinilah, sebuah konflik itu muncul. Konflik antar pemeluk agama mengandung muatan kompleks dan tidak sekedar menyentuh dimensi keyakinan dari agama yang dipeluk. Tetapi juga terkait dengan kepentingan sosial, ekonomi, politik dan sebagainya. Konflik antar pemeluk agama amat mudah ditunggangi kelompok kepentingan, sehingga konflik yang terjadi adalah konflik kepentingan yang mengatasnamakan Tuhan dan agama.

Seperti dikatakan sebelumnya, bahwa teori konflik muncul disebabkan adanya hegemoni paradigma teori struktural-fungsional. Teori struktural-fungsional merupakan suatu teori yang menekankan adanya suatu ketertiban (order) dalam kehidupan masyarakat. Menurut teori ini, masyarakat dipandang sebagai suatu sistem sosial yang terdiri dari bagian-bagian yang saling berkaitan dan menyatu dalam keseimbangan. Teori ini mempunyai asumsi bahwa setiap tatanan (struktur) dalam sistem sosial akan berfungsi pada yang lain, sehingga bila fungsional tidak ada, maka struktur itu tidak akan ada atau hilang dengan sendirinya. ${ }^{9}$

8 Abdul A'la Al-Maududi, "Konflik Kekerasan; Antara Politisasi Agama, Etnisitas, dan Politik Kekuasaan", Paramedia, Vol. 8, No. 3 (2007), h.4. Hubungan sosial yang bersifat dominatif pada akhirnya akan melahirkan hukum tradisional dan primitif yaitu siapa yang kuat itulah yang menang dan berkuasa serta dialah yang membuat hukum. Konflik sesungguhnya lahir karena dilatarbelakangi makin meluasnya dogma teori struktural-fungsional, yang menurut sebagian pandangan tokoh sosial dianggap sudah tidak lagi sejalan dengan perubahan dan perkembangan masyarakat. Jika demikian, maka konstruksi teori tidak akan membantu kita untuk memahami secara proporsional dan menerapkan sebuah peristiwa (kejadian). Oleh karena itu, konflik yang timbul dalam suatu kondisi akan dapat membangun kesadaran baru bagi perubahan kondisi secara lebih baik dan dinamis dalam kehidupan masyarakat.

9 Umi Sumbulah, Agama dan Kekerasa: Menelisik Akar Kekerasan dalam Studia Philosophica et Theologia, Vol. 5. No. 1 Maret 2005 
Berangkat dari hal di atas, teori struktural-fungsional kiranya dapat disederhanakan menjadi sejumlah proposisi. Pertama, masyarakat merupakan suatu perpaduan nilai-nilai budaya bersama yang dilembagakan menjadi norma-norma sosial dan dimantapkan oleh individu-individu kepada sebuah motivasi. Semua ini didasarkan atas konsep relasional antara subyek dan obyek yang dalam bahasa fenomenologi disebut inter subyektivitas atau dunia alterego.

Kedua, realitas sosial merupakan relasi-relasi yang membentuk sistem sosial yang mempunyai dua ciri khas; pertama, konsep fungsi yang dimengerti sebagai sumbangan kepada keselamatan dan ketahanan. Konsep ini dititik beratkan pada berjalannya bagian-bagian dalam sistem sosial sesuai fungsinya yang saling bergantung dan tak ada unsur yang terpisah satu sama lainnya. Kedua, adanya konsep pemeliharaan keseimbangan sebagai ciri utama dari tiap-tiap sistem sosial. Konsep ini merupakan tujuan yang diharapkan dengan mengandaikan bahwa saling bergantung merupakan upaya keseimbangan (equilibrium).

Ketiga, masyarakat adalah suatu sistem yang secara keseluruhan terdiri dari bagian-bagian yang saling tergantung (interdependensi). Keseluruhan sistem yang utuh menentukan bagian-bagian. Artinya, bagian yang satu tidak dapat dipahami secara parsial dan terpisah kecuali dengan mempertahankan hubungan dengan sistem keseluruhan yang luas, di mana bagian- bagian menjadi unsurnya.

Keempat, tiap-tiap masyarakat merupakan struktur yang terdiri dari unsur-unsur yang relatif kuat dan mantap, berintegrasi satu sama lain dengan baik. Orang lebih banyak bekerja sama daripada menentang, biarpun telah terjadi pergantian dan perubahan-perubahan apa pun. Masyarakat diharapkan dapat menjalankan tugas sesuai fungsinya masing-masing, sehingga sistem yang dibangun akan berjalan dengan sendirinya.

Karena itu, sulit akan terjadi pertentangan dan konflik, jika seluruh fungsi berjalan sesuai dengan kesadaran tugasnya. Agama tidak lagi dipahami sebagai sebuah keimanan dan kepercayaan, tetapi juga dijadikan sebagai way of life dan kebutuhan asasi manusia akan pentingnya makna religiusitas kehidupan manusia, sehingga hubungan antar pemeluk agama berjalan damai, agama berfungsi sebagai penyelamat dan pembebas benar-benar berjalan mantap dengan penuh kesadaran bagi pemeluknya. Di sinilah keharmonisan antar pemeluk agama tercipta dengan sendirinya tanpa adanya sebuah rekayasa semu.10

10 Dengan mengikuti proposisi-proposisi di atas, hubungan antar pemeluk agama, baik yang seagama maupun antar agama, dalam perspektif teori struktural-fungsional menunjuk kepada

RI'AYAH, Vol. 02, No. 01 Januari-Juni 2017 


\section{Fenomena Kekerasan Sosial Berbasis Agama}

Kita tak perlu berharap bahwa dalam masyarakat yang sangat beragam, terdiri dari individu dan kelompok yang berbeda-beda identitasnya, ketegangan atau konflik tak akan pernah terjadi. Akan tetapi selayaknya kita terus mengupayakan agar kekerasan tidak menjadi modus interaksi dalam merespons keragaman itu. Kasus lama terkait Ahmadiyah mencapai tingkat kekerasan baru dengan drastis, tiga orang Ahmadiyah terbunuh dengan mengenaskan di Cikeusik, dan minggu berikutnya beberapa fasilitas publik, termasuk gereja, menjadi sasaran amuk massa di Temanggung setelah pengadilan terkait kasus penodaan selesai. Kekerasan lain dengan skala besar melibatkan pembakaran bangunan pesantren dan memaksa ratusan orang pengikut Syi'ah menjadi pengungsi selama sebulan, terjadi di Sampang, Madura. Pada sepanjang tahun 2011 SETARA Institute mencatat 244 peristiwa pelanggaran kebebasan beragama/berkeyakinan yang mengandung 299 bentuk tindakan, yang menyebar di 17 wilayah pemantauan dan wilayah lain di luar wilayah pemantauan. Terdapat 5 propinsi dengan tingkat pelanggaran paling tinggi yaitu, Jawa Barat (57) peristiwa, Sulawesi Selatan (45), JawaTimur (31), Sumatera Utara (24), dan Banten (12) peristiwa.

Berikut ini sejumlah ulasan kasus-kasus yang terjadi yang merujuk ke Laporan Kondisi Kebebasan Beragama/Berkeyakinan : SETARA Institute bertajuk: Politik Diskriminasi Rezim Susilo Bambang Yudoyono, yang dipublikasikan oleh Pustaka Masyarakat Setara edisi Februari 2015 serta Laporan Tahunan Kehidupan Beragama di Indonesia 2011 - CRCS UGM yang dipublikasikan oleh Sekolah Pascasarjana Program Studi Agama dan Lintas Budaya UGM edisi Januari 2016.

\section{a. Kasus Syi'ah Sampang}

Penyerangan terhadap kelompok Islam Syi'ah terjadi pada Minggu, 26 Agustus 2012 di Dusun Nanggernang, Desa Karang Gayam, Kecamatan Omben, Sampang, Madura sekitar pukul 11.00 WIB. Akibat dari peristiwa ini, seorang warga dinyatakan tewas, lima orang luka, dan empat di antara korban luka dalam kondisi kritis. Selain menyerang dan melukai warga, kelompok penyerang juga membakar rumah-rumah pengikut Syi'ah yang ada di dua desa, yaitu Desa Karang Gayam dan Desa Bluuran, Kecamatan Omben, Sampang.

adanya keharmonisan dan kedamaian yang akan dapat terciptakan, karena semua unsur, bagian merupakan kesatuan yang tidak bisa dipisahkan, sehingga semua pemeluk agama dalam interaksi sosial keagamaannya akan berjalan sesuai dengan fungsinya. Bahkan para pemeluk agama dapat menyadari tugas dan fungsi pelaksanaan agamanya, dan pemeluk agama yang lain juga akan menyadari eksistensi fungsinya masing-masing. Umi Sumbulah, Agama dan Kekerasa: Menelisik Akar Kekerasan dalam Studia Philosophica et Theologia, Vol. 5. No. 1 Maret 2005. 
Peristiwa ini adalah kasus ketiga setelah yang kedua pada bulan Desember 2011. Polri menegaskan konflik masyarakat di Sampang, Madura bukan dilatarbelakangi perbedaan paham Sunni dan Syi'ah. Konflik di Sampang murni karena persoalan pribadi antara dua tokoh masyarakat yang juga kakak beradik, Tajul Muluk (Syi'ah) dan Rois (Sunni). ${ }^{11}$

Kepolisian Daerah Jawa Timur telah menetapkan Roisul Hukuma, adik pemimpin Syi'ah Sampang sebagai tersangka. Ia dijerat pasal pembunuhan, pasal penganiayaan berat, pasal pengeroyokan dan pengrusakan, serta pasal turut membantu kejahatan. Sementara. ${ }^{12}$

Pihak keamanan, ormas, partai politik, dan Pemprov Jawa Timur mengecam tindakan anarkis tersebut. Gubernur Jawa Timur meminta kepolisian melakukan pendekatan persuasif untuk melerai konflik keluarga tersebut. Lebih jauh, Gubernur Jawa Timur menolak desakan melarang keberadaan Syi'ah di Jawa Timur. Sampai saat ini MUI Pusat pun tidak melarang Syi'ah. Satu hal yang mengherankan adalah pernyataan Syaifullah Yusuf, Wakil Gubernur Jatim, yang tak lama setelah penyerangan mengajukan usulan relokasi warga Syi'ah, agar konflik tak terjadi lagi. Solusi ini seakan-akan ingin menyelesaikan masalah yang muncul karena perbedaan dengan melenyapkan kelompok berbeda secara paksa. Dapat dibayangkan bagaimana jika hal ini menjadi pola penyelesaian konflik: suatu kelompok mayoritas hanya perlu memberikan bukti (misalnya dengan menyerang atau menghancurkan properti suatu kelompok) bahwa keberadaan suatu kelompok minoritas yang berbeda tak diinginkan, dan kemudian usulan itu dipenuhi pemerintah melalui relokasi. ${ }^{13}$

Respons polisi perlu juga dicatat. Sebenarnya, isu akan adanya penyerangan sudah diketahui warga Syi' ah seminggu sebelumnya. Warga Syi'ah sudah menginformasikan rencana tersebut ke pihak keamanan. Akan tetapi pihak keamanan terlambat merespons laporan tersebut. Pesantren sudah hancur, pihak keamanan baru datang ke lokasi.

11 Ahmad Zainul Hamdi," "Klaim Religious Authority dalam Konflik Sunni-Syi'i Sampang Madura", ISLAMICA. Vol. 6, No. 2 (Maret 2012).

12 Syi'ah di Sampang sebenarnya sudah ada sejak 1980-an, dan beribadah secara terbuka dan terang-terangan sejak 2004. Tidak ada masalah dengan warga pada waktu itu. Pada tahun 2006 mulai ada penyerangan terhadap pesantren dan warga Syi'ah, meskipun tidak seberat 29 Desember 2011 dan 26 Agustus 2012. Kekerasan ini diduga karena mulai bermunculannya tokoh-tokoh agama. Pada tahun 2009, MUI Sampang bersama dengan Kapolsek dan Danramil membuat pernyataan bahwa Syi'ah bukanlah aliran sesat karena tidak ada penyimpangan. Efek dari pernyataan tersebut, warga Syi'ah di Sampang terlindungi. Akan tetapi, warga non-Syi'ah setempat justru semakin keras menentang keberadaan mereka. Lihat juga Handoko, Imam Priyo, “Upaya Menjadikan ...”, Kompas. Rabu 15 Februari 2006.

13 Ahmad Zainul Hamdi,, "Klaim Religious., h.32 
Keterlambatan respons polisi ini tak hanya terjadi sekali, tetapi kerap berulang sebagaimana terjadi pada Agustus 2012 kita khawatir, sikap ini akan menjadi pola tindakan polisi menghadapi ancaman penyerangan.

\section{b. Pembakaran Gereja di Aceh Singkil (13 Oktober 2015)}

Bentrok antarwarga di Kecamatan Gunung Meriah, Kabupaten Aceh Singkil, Nangroe Aceh Darussalam (NAD) berimbas pada pembakaran sebuah gereja dan menewaskan dua orang warga serta empat orang luka-luka. Dari dugaan sementara pihak kepolisian, motif peristiwa tersebut berkaitan dengan pemilihan kepala daerah (pilkada) di wilayah tersebut. Pada peristiwa yang terjadi Selasa (13/10) siang itu, disinyalira bentrokan memiliki unsur politis. "Ada lawan-lawan politik juga, kemungkinan terkait pilkada. Bukan tanpa alasan hal itu terjadi, mengingat pilkada akan diselenggarakan dalam waktu dekat di daerah tersebut. Meski demikian, unsur sentimen agama tetap saja menjadi isu sentral yang melatarbelakangi pecahnya konflik tersebut. Hal ini terlihat ketika amarah warga dilampiaskan dengan perusakan gereja. Pada konflik/kekerasan sosial ini, Kepolisian menetapkan sepuluh tersangka dalam peristiwa bentrokan antarwarga di Aceh Singkil.

\section{c. Konflik/kekerasan sosial Tolikara (17 Juli 2015)}

Pada tanggal 17 Juli 2015 pukul 07.00 WIT bertempat di lapangan Makoramil 1702-11/Karubaga distrik karubaga kabupaten Tolikara telah berlangsung kegiatan shalat idul fitri $1436 \mathrm{H}$ yang dipimpim oleh Ustad Junaedi dan berujung pada keributan antara Jemaat Gidi yang sedang melaksanakann seminar internasional yang dipimpin oleh Pendeta Marthen Jingga dan Harianto Wanimbo (Korlap) dengan Umat muslim yang sedang melaksanakan shalat Ied.

Pukul 07.00 WIT saat Jamaah muslim akan memulai kegiatan shalat Ied di lapangan Makoramil 1702-11/Karubaga Pendeta Marthen Jingga dan sdr. Harianto Wanimbo (koorlap) yang menggunakan megaphone berorasi dan menghimbau kepada jamaah shalat Ied untuk tidak melaksanakan ibadah shalat Ied di Tolikara.

Pukul 07.05 WIT Saat memasuki Takbir ke 7 ketika shalat massa yang di koordinir dari Pendeta Marthen Jingga dan Harianto wanimbo (Koorlap) mulai berdatangan dan melakukan aksi pelemparan batu dari bandara Karubaga dan luar lapangan Makoramil 1702-11/karubaga yang meminta secara paksa untuk membubarkan kegiatan Shalat Ied dan mengakibatkan kepanikan jamaah shalat Ied yang sedang melaksanakan shalat.

\section{d. Konflik Sara di Tanjung Balai Asahan (30 Juli 2016)}

Konflik anarkis terjadi juga di Tanjungbalai, Asahan, Sumatera Utara. Konflik bernuansa SARA ini bermula dari seorang wanita keturunan 
Tionghoa M (41) yang mengajukan protes pada takmir Masjid AlMakhsum, untuk mengecilkan volume suara azan di Masjid, karena merasa terganggu. Teguran tersebut katanya telah dilayangkan beberapa kali. Beberapa waktu kemudian datang takmir masjid bersama jamaah mendatangi $\mathrm{M}$ di rumahnya, Jalan Karya, Tanjung Balai, pada Jumat 29 Juli 2016. Namun, aksi tersebut berhasil dicegah, dan kumpulan massa berangsur pulang. Namun karena terprovokasi postingan media sosial, massa tersebut kembali datang ke rumah $\mathrm{M}$ untuk menghancurkan dan membakar rumah tersebut. Beruntung, aksi tersebut gagal karena dicegah warga kompleks setempat. Tak puas, ratusan warga kemudian mendatangi Vihara dan Klenteng, lalu melampiaskan kemarahan mereka dengan membakar tempat ibadah tersebut. Konflik berujung pada terbakarnya 2 Vihara dan 5 Klenteng.

e. Pembubaran Kebaktian Gereja Pra-Natal di Bandung (06 Desember 2016

Kasus berikutnya terjadi di Kota Bandung. Sikap intoleransi keberagamaan yang ini lebih frontal bahkan terkesan sadis. Lagi-lagi, sekelompok orang/massa/ormas membubarkan prosesi ibadah yang sedang dilaksanakan oleh ummat Kristiani. Pembubaran acara praNatal di Sabuga, Bandung, Selasa (06/12) malam oleh kelompok intoleran lagi-lagi menggunakan alasan perizinan yang belum lengkap, dan ini menurut aktivis keberagaman dinilai sebagai alasan 'mengadaada'.

Berawal dari Massa yang mengatasnamakan diri Pembela Ahlus Sunnah (PAS) mendatangi lokasi penyelenggaraan Kebaktian Kebangunan Rohani (KKR) di Gedung Sabuga, Jalan Tamansari, Kota Bandung. Pihak PAS meminta panitia KKR menyelenggarakan kegiatan keagamaan tersebut di rumah ibadah. Hasil kesepakatan antar kedua pihak yang dimediasi polisi membuahkan hasil yaitu acara KKR ibadah Natal sesi kedua tidak dilanjutkan dengan berbagai pertimbangan.

Sesekali seruan keras diiringi takbir yang dilontarkan agar jemaat berhenti bernyanyi bisa terdengar, namun juga terbenam oleh koor 'Malam Kudus' dari jemaat STEMI. Sejumlah laporan menyebut kelompok yang menamakan diri Pembela Ahlus Sunnah dan Dewan Dakwah Islam menghentikan acara tersebut karena menganggap acara keagamaan tidak seharusnya dilakukan di tempat umum.

Dari berbagai kasus kekerasan/konflik sosial di atas, suatu hal yang sangat menggelitik di dalam pikiran kita semuanya adalah kebanyakan pelaku kekerasan tersebut mengaku beragama Islam. Apakah memang benar Islam mengajarkan kekerasan? Bagaimana dengan agama lain? Ternyata, sebagaimana Islam, agama lain salah satunya Kristen juga 
memiliki penganut yang radikal. Sebagai contoh, ada kasus kalangan Kristen di daerah mayoritas Kristen mencegah pembangunan masjid Muslim Sunni. Individu yang terkena dampaknya beragam, dari mereka yang minta izin mendirikan rumah ibadah hingga yang menginginkan status kepercayaan dicantumkan pada kartu tanda penduduk hingga anakanak yang dilecehkan guru dan murid lain di sekolah. Selain itu, Milisi Kristen terlibat dalam kekerasan terhadap minoritas Muslim di Kepulauan Maluku dan Poso setelah Presiden Suharto lengser dari kekuasaan pada 1998. Mayoritas Kristen juga sering menghambat pembangunan masjid di daerahnya, kebanyakan di kawasan Indonesia timur.

Tetapi analisis obyektif memang diperlukan untuk menjawab rangkaian pertanyaan di atas, termasuk dengan melibatkan dimensi sosiologis agama yang sedikit banyak mempengaruhi corak keberagamaan individu dan masyarakat. Dari beberapa telaah terhadap agama terutama yang bertitik tolak dari ilmu-ilmu sosial, misalnya yang dilakukan oleh Charles Glock dan Rodney Stark serta Joachim Wach dalam J. Milton Yinger, dimensi sosial agama-Glock dan Stark menggunakan konsep the consequeces dimension. Sedangkan Wach memilih konsep a system of social relationships- tidak pernah luput dari sasaran analisis untuk memahami dialektika antara agama dengan kehidupan sosial, atau sebaliknya. Demikian juga sebaliknya, banyak kehidupan sosial manusia yang tidak luput dari pengaruh agama. Adanya dialektika ini antara lain dibuktikan oleh Max Weber melalui penelitiannya yang sangat populer, The Protestant Ethic and the Spirit of Capitalism. Melalui penelitian ini, di samping Max Weber secara meyakinkan menemukan adanya afinitas antara agama dengan perkembangan kapitalisme, ia secara meyakinkan pula mendekonstruksi tesis Karl Marx tentang determinisme ekonomi (economic determinism), dan menawarkan argumen baru sebagai berikut: "... a new set of religious ideals can transform people`s daily behaviour, including their behaviour in the economic sphere".

\section{Pola/bentuk kekerasan Sosial}

Kejadian-kejadian dan aksi-aksi kekerasan sosial yang tengah menimpa manusia, khususnya di Indonesia belakangan ini sangatlah banyak dan beraneka ragam sesuai dengan kondisi dan keadaan yang diharapkan oleh para pelakunya. Hal ini didasarkan pada tujuan dan guna meraih sasaran dan target mereka. Secara singkat, bentuk-bentuk aksi kekerasan sosial dapat dibagi ke dalam 3 macam golongan ${ }^{14}$ : Kekerasan Fisik. Yaitu peristiwa-peristiwa atau bentuk kekerasan yang

14 Ihsan Ali Fauzi, et al., Laporan Penelitian Pola-pola Konflik Keagamaan di Indonesia (19902008), Jakarta: Yayasan Wakaf Paramadina (YWP), Magister Perdamaian dan Resolusi Konflik, Universitas Gadjah Mada (MPRK- UGM), The Asia Foundation (TAF), 2009. 
sekarang menjadi puncak sorotan manusia seperti pelededakan, bom bunuh diri, pembajakan, dan seterusnya. Berbagai kejadian pahit dari kekerasan fisik ini telah telah tercatat dalam sejarah. Seperti di Indonesia seperti Bom Bali 1, Bom Bali 2, Bom Kedutaan Australia di Jakarta, Bom Marriot 1, Bom Marriot 2 dan lain-lain.

a. Kekerasan Psikologis (Kejiwaan). Yaitu suatu bentuk-bentuk kekerasan sosial yang berupa suatu ancaman psikologis terhadap suatu subjek atau objek tertentu, seperti misalkan berupa teror ancaman bom melalui media tertentu seperti telepon, pesan singkat, surat, email, artikel blog, website dll, yang bertujuan untuk menimbulkan kepanikan. Seperti yang terjadi pada teror gereja pada malam natal, teror gedung kedutaan AS dan lain-lain.

b. Kekerasan Ideologi (pemikiran/pemahaman). Kekerasan sosial jenis ini jauh lebih berbahaya dari terorisme fisik dan psikologi. Sebab seluruh bentuk kekerasan fisik yang terjadi bersumber dari dorongan ideologi para pelakunya, baik itu dari kalangan orang-orang tidak beragama yang merupakan sumber kekerasan sosial di muka bumi ini, atau dari kalangan kaum beragama yang telah menyimpang pemikirannya dari jalan ajaran mereka, khususnya dalam hal ini kaum muslimin yang telah menyimpang dari ajaran Islam yang sesungguhnya.

Preposisi di atas, ternyata memberikan kejelasan bahwa relasi agama dan kerukunan sesungguhnya memiliki satu tujuan, yaitu perdamaian. Kerukunan menegasikan konflik sosial dan merupakan cita-cita setiap umat manusia. Sedangkan agama juga mengharuskan rekonsiliasi demi membangun kerukunan antarumat beragama agar tercapai hidup dalam suasana damai, saling menghormati dan menghargai walau berbeda agama.

Menurut Setara Institute dan Wahid Institute, format Kekerasan sosial yang terjadi di Indonesia menunjukkan trend peningkatan. Tercatat ada 250 kasus berkenanan dengan kekerasan berlatar belakang agama di 2010, sedangkan di 2011 dilaporkan ada 197 kasus. Terdapat 216 kasus serangan terhadap minoritas agama pada 2012, 244 kasus pada 2012, dan 264 kasus pada $2014 .^{15}$

\section{Penyebab Kekerasan Sosial dan Justifikasi Agama}

Menurut Abdul Aziz Ustman Altwaridji, faktor utama terjadinya kekerasan dalam agama adalah bahwa konflik itu menunjukkan dan menggambarkan serta menjelaskan perjuangan suatu kelompok yang selalu dipenuhi kekerasan untuk keperluan dasar seperti keamanan dan

\footnotetext{
15 the Wahid Institute, Laporan Kebebasan., h. 10
} 
lain-lain. Kedua, adanya faktor perampasan kebutuhan manusia yang kemudian diartikulasikan secara kolektif. Kebutuhan manusia yang kemudian dinilai sebagai hak dasar itu adalah keamanan, pengembangan (hak mencari nafkah), akses politik, dan identitas (ekspresi budaya dan religious). Ketiga, adalah faktor pemerintah yang tidak mampu memuaskan kenginan dasar individu dan kelompok identitas. Padahal, jaminan tentang hak-hak dasar masing-masing penduduknya sudah jelas regulasinya. Sebut saja UU Jaminan Kebebasan Beragama.

Memperkuat preposisi sekaligus argumentasi di atas, Ada dua yang menjadi penyebab mengapa format kekerasan sosial berbasis agama terus terulang. Pertama, kapasitas negara yang memang lemah sehingga tanpa sengaja membuat wewenang monopoli kekerasan sosial itu terbagi kepada sipil. Dan celakanya, kekerasan sosial tersebut menyeret agama sebagai alat legitimasi untuk melakukan tindakan kekerasan dimaksud. Inilah yang disinyalir sebagai sebuah kerawanan laten menurut sosiolog Jerman, Max Weber (1946). Max Weber melihat bahwa tanpa ada institusi resmi yang mampu memonopoli kekerasan, negara akan runtuh dan muncul anarkis. Kedua, belakangan makin kentara bahwa yang dihadapi bangsa ini ternyata bukan semata negara yang loyo, tapi negara yang sengaja memberi peluang bagi kelompok tertentu mengintimidasi dan memberangus hakhak kelompok lain dengan kekerasan yang berlindung di balik kesucian agama. Pendeknya, meminjam parafrasa sejarawan Fernand Braudel (1966), “Di balik para bandit, ada bantuan dari oknum aparat negara. ${ }^{16}$

Dalam tradisi Islam maupun Kristen ketika memahami luas dan dinamika hubungan yang tepat antara penguasa dan agama serta bagaimana agama atau sistem kepercayaan yang lain dapat dipraktikkan secara bebas di dalam suatu wilayah, telah melahirkan persoalan justifikasi (pembenaran) atas praktik-praktik kekerasan sosial berbasis agama yang kemudian sering dikenal "perang suci". Adanya pembenaran antara dar alIslam dan dar al-harb dalam Islam maupun civitas dei dan civitas terranae dalam Kristen mencerminkan persoalan tentang sosok yang dapat memberi kuasa dalam menggunakan kekuatan untuk mencapai tujuantujuan politis dari agama. Pembedaan itu dibangun untuk membuka pintu kekerasan atau tuntutan untuk melakukan "perang suci" guna memenuhi alasa-alasan yang bukan agama. Akibatnya, usaha terbaik dari pembedaan itu justru dikisruhi/direcoki oleh unsur manusianya sendiri yang mengarah pada hal-hal yang sangat vested interest. Sehingga keadilan yang diidealkan dalam praktiknya merupakan ketidakadilan itu sendiri, dan

16 Astrid S.Susanto, Pengantar Sosiologi dan Perubahan Sosial, (Jakarta: Binacipta, 1985), h. 29 
kondisi esensialnya adalah penciptaan wilayah konflik sosial, baik dalam konteks internal maupun eksternal.

\section{Kegagalan Upaya Prevensi Pencegahan Kekerasan Sosial}

Dalam upaya menanggulangi terjadinya tindak kekerasan sosial, khususnya yang bermotif dan berlatarbelakang agama, berbagai langkah yang bersifat preventif telah diambil. Berbagai Regulasi dan Peraturan sebenarnya telah dikeluarkan Pemerintah. Semua Langkah prevensi tersebut dilakukan dalam upaya bertujuan menanggulangi isu-isu kekerasan sosial yang terjadi di Indonesia. Namun, berdasarkan pengamatan periset Human Rights Watch, banyak peraturan yang justru cenderung memunculkan resistensi. Resistensi tersebut terlihat dari aspek memungkinkannya pihak agama mayoritas untuk menekan agama minoritas. Misalnya, Surat Keputusan Bersama (SKB) Rumah Ibadah yang dibuat tahun 1969 dan direvisi tahun 2006, mengharuskan pembangunan rumah ibadah berdasarkan "keperluan nyata dan sungguh-sungguh" dan "komposisi jumlah penduduk." Data Persekutuan Gereja-gereja di Indonesia menunjukkan bahwa 430 gereja dipaksa ditutup pada Januari $2005 .{ }^{17}$

Contoh Regulasi lainnya adalah dengan dikeluarkannya Surat Keputusan Bersama (SKB) Anti-Ahmadiyah yang dibuat oleh Menteri Agama, Jaksa Agung, dan Menteri Dalam Negeri pada tahun 2008. SKB ini, seperti tercatat dalam Human Right Watch, "membuka pintu bagi para gubernur serta bupati dan walikota membuat ketentuan peraturan antiAhmadiyah." Tercatat 22 peraturan walikota dan bupati di Indonesia telah mengeluarkan regulasi anti-Ahmadiyah semenjak munculnya SKB tersebut. Pada dimensi lain, imbas dari SKB ini "berbuntut" pada diskrimasi yang dialami oleh agama-agama lokal. Secara empirik, hal Ini dialami oleh Dewi Kanti, penganut Sunda Wiwitan yang adalah satu dari sekian banyak agama lokal di Indonesia. Ia menceritakan bagaimana kantor catatan sipil menolak menerima pernikahannya karena tidak mengakui agama Dewi. Ini membuat anak-anaknya kemudian dianggap lahir di luar nikah, dan pada akta kelahiran mereka, diperlukan dokumen lain untuk bisa mencantumkan nama ayahnya. ${ }^{18}$

17 Slamet Effendy Yusuf, "Review 5 Tahun Kehidupan Umat Beragama di Indonesia: Perspektif MUI", Makalah pada Kongres FKUB di Jakarta, 21-22 November 2011.

18 Selama era Suharto, warga Indonesia diwajibkan mencantumkan agama mereka pada kartu tanda penduduk, memilih satu dari lima agama yang diakui resmi oleh pemerintah-sebuah praktik yang mendiskriminasi, dan menempatkan posisi lemah, para penganut ratusan keyakinan minoritas. Meski Undang-Undang Administrasi Kependudukan sekarang memberi warganegara pilihan untuk mengabaikan atau menyertakan agama/ keyakinan mereka pada kartu tanda penduduk, mereka yang berharap mencantumkan keyakinan atau aliran kepercayaan tetap harus memilih daftar enam agama yang diakui hukum Indonesia. Individu yang enggan mencantumkan 
Berbagai peristiwa bisa kita saksikan di mana polisi gagal mengambil tindakan untuk mencegah kekerasan sosial atas nama agama atau gagal menegakkan hukum sesudah kejadian. Polisi terlalu pasrah dan sering tak melakukan investigasi yang layak dan terstandarisasi pada berbagai kasus kekerasan sosial yang dialami oleh minoritas agama. Aparat penegak hukum seperti "enggan" dan menunjukkan kongkalikong dengan para penyerang. Belum lagi sistem peradilan pidana kita, semakin memperparah dengan tidak membuktikan sebagai benteng pembela minoritas. Pada beberapa kasus kekerasan sosial yang diproses ke pengadilan, para jaksa menuntut dakwaan lemah bagi para pelaku kejahatan berat, dan para hakim pun mendukungnya.

Pemerintah Indonesia, dalam undang-undang dan perjanjianperjanjian internasional, menghormati hak kebebasan beragama. Kebebasan beragama jadi bagian dari konstitusi Indonesia sejak kemerdekaan 1945. Pada 2005, Indonesia meratifikasi Kovenan Internasional Hak-hak Sipil dan Politik (ICCPR), yang menjamin dalam pasal 18 ayat (2), "Tidak seorang pun dapat dipaksa sehingga terganggu kebebasannya untuk menganut atau menetapkan agama atau kepercayaannya sesuai dengan pilihannya," dan pasal 27, "Orang-orang yang tergolong dalam kelompok minoritas tidak boleh diingkari haknya dalam masyarakat bersama anggota kelompoknya yang lain, untuk menikmati budaya mereka sendiri, untuk menjalankan dan mengamalkan agamanya sendiri."

\section{Analisis Resolusi Konflik}

Analisis ini akan dimulai dari pernyataan Alexander Philips Sitinjak yang menyatakan bahwa : "Agama bukanlah candu bagi masyarakat, Agama itu pembenaran akan keyakinan yang telah menjadi tradisi dan budaya. Ketika pembenaran itu bertemu dengan pembenaran yang lain, distorsi bisa saja terjadi yang acapkali kaum minoritas menjadi korban dari pembenaran atas keyakinan itu sendiri, yang belum tentu apakah keyakinan tersebut bisa dipertanggung jawabkan atau tidak.

\section{Resolusi Memahami Sumber Konflik/Kekerasan Sosial}

a. Apakah ini "konflik agama"?

Setiap ada konflik yang melibatkan atau menggunakan simbolsimbol agama dan mengenai umat beragama, hal pertama yang perlu

keyakinan berisiko dicap "tak bertuhan" oleh ulama atau pejabat, bahkan ada kemungkinan dijadikan subyek pidana penodaan agama. Pada 2012, seorang yang terbuka menyatakan diri ateis, seorang ustad Syiah, dan seorang pemimpin tarekat dipenjara dengan vonis penodaan agama walau mereka mencantumkan agama Islam pada KTP mereka. Jajang Jahroni, Tekstualisme, Islamisme dan Kekerasan Agama, dalam: Islamlib.com, 07 Agustus 2008. 
dipahami adalah bahwa setiap konflik (dan, sebetulnya, setiap peristiwa sosial) tidak pernah memiliki hanya satu sebab tunggal. Istilah "konflik agama" bisa saja digunakan untuk peristiwa dimana simbol agama dirusak, misalnya, atau identitas keagamaan orang-orang yang terlibat dalam konflik itu (pelaku atau korban) tampak nyata. ${ }^{19}$

Namun setiap konflik biasanya memiliki banyak penyebab. Konflik agama tidaklah sepenuhnya mengenai agama. Sebagai contoh, dalam laporan CRCS mengenai Politik Lokal dan Konflik Keagamaan, semua konflik keagamaan yang dibahas menunjukkan ciri itu. Konflik yang dibahas termasuk kasus penyerangan sebuah komunitas Syi'ah di Sampang, kasus Gerjea HKBP Filadelfia di Bekasi, dan kasus pembangunan Masjid Nur Musafir di Batulpat, Kupang.

Ketiga kasus itu menunjukkan bagaimana konflik terjadi karena bertemunya kepentingan-kepentingan politik lokal dengan (manipulasi) simbol keagamaan. Inilah rumusan yang cukup kuat untuk digeneralisir: apa yang disebut "konflik agama" mungkin memiliki unsur identitas agama, tapi jarang menjadi penyebab utama. Menyebut konflik agama seperti ini sebagai diakibatkan intoleransi adalah penjelasan yang terlalu mudah-sama halnya dengan konflik-konflik agama di banyak tempat lain.

Dalam kasus di Tolikara misalnya, konteks penting adalah kompleksitas dan kerentanan persoalan Papua pada umumnya. Kerentanan ini, seperti bisa dilihat dalam beragam kasus-kasus nonagama lainnya di Papua, kerap direspon oleh aparat keamanan secara represif dengan menggunakan senjata-untuk melukai atau membunuh. Secara lebih khusus, Kabupaten Tolikara sendiri cukup rawan-politik, seperti tampak dalam konflik di sekitar Pilkada pada Februari 2015.

Satu kecenderungan lain adalah adanya persaingan antara Gereja Injili di Indonesia (GIDI) yang mendominasi di daerah itu dengan kelompok agama lainnya (termasuk dengan Kristen denominasi yang berbeda). Situasi ini bisa jadi sudah menyediakan lahan yang siap diolah sewaktu-waktu untuk meletusnya konflik jenis apapun. Maka hal remeh, seperti soal speaker bisa dengan mudah meletuskan konflik kekerasan, bahkan merenggut korban jiwa. Jadi bagaimana mengidentifikasi "kasus Tolikara"? Apakah kasus Tolikara adalah kasus GIDI, atau kasus konflik yang diletuskan menjadi kekerasan akibat aparat yang represif secara berlebihan, atau kasus lain?

19 (Lebih jauh, lihat pendefisian "konflik agama" dalam Rizal Panggabean dan Ihsan AliFauzi,Pemolisian Konflik Keagaman di Indonesia, PUSAD Paramadina dan MPRK UGM, 2014, hal. 12, yang berbicara mengenai karakteristik, bukan sebab, konflik agama. 


\section{b. Agama : sumber perdamaian?}

Penanganan represif kerap muncul dari kesan yang sering dimunculkan bahwa Papua adalah daerah yang rawan konflik. Tapi kalaupun ada kebenaran dalam kesan itu, penyebab utamanya adalah konflik yang selama lebih dari 50 tahun terakhir ini tidak berhasil diselesaikan, utamanya oleh pemerintah pusat. Isu utama "kerawanan" sesungguhnya jauh dari agama. Dalam Papua Road Map, misalnya, yang merupakan hasil kajian LIPI (2008), ada empat masalah utama yang diidentifikasi sebagai akar persoalan Papua, dan di sana, agama sama sekali bukan sumber masalah. Tanpa mengingkari adanya gesekangesekan antar umat beragama (Kristen dengan Muslim, denominasi Kristen tertentu dengan denominasi lain dan dengan Katolik, juga antara kelompok-kelompok Muslim sendiri), lembaga-lembaga keagamaan arus utama sebetulnya justru lebih dikenal sebagai aktor perdamaian.

Dalam konteks ini salah satu contoh yang bisa diambil adalah Pater Neles Tebay, seorang pemimpin Katolik yang dikenal juga sebagai Koordinator Jaringan Damai Papua. Dalam pernyataannya mengenai insiden di Tolikara, Pater Neles mengungkapkan, "Budaya Papua tidak mengajarkan orang untuk mengganggu, apalagi membakar tempat ibadah." Menurutnya, pembakaran mushala di Tolikara adalah peristiwa pertama dalam sejarah Papua di mana sebuah tempat ibadah dibakar. "Maka, sebagai orang Papua, saya memohon maaf atas peristiwa yang melanggar norma adat ini," katanya.

Dalam sebuah diskusi pada tahun 2013 yang diselenggarakan Program Studi Agama dan Lintas Budaya UGM (CRCS) bersama STAIN Papua dan melibatkan tokoh-tokoh agama, yang muncul justru adalah peran agama sebagai sumber modal sosial untuk perdamaian. Kisahkisah kerukunan antar agama di masa kecil muncul dari banyak peserta. Ikatan adat yang amat kuat mampu melampaui batas-batas agama. Beberapa dari simbol-simbol adat itu telah menjadi objek penelitian, misalnya tulisan Budi Asyhari, Mutiara Terpendam Papua.

Ikatan yang kuat dan melampaui batas agama itu sebetulnya juga muncul di banyak tempat di Indonesia. Sebagian besar meyakini bahwa modal sosial yang berakar kuat dalam sejarah itu sebetulnya masih ada. Namun, dan ini adalah juga fenomena yang muncul di banyak tempat, ikatan itu dalam perkembangannya dapat kalah oleh kekuatankekuatan sosial-politik-ekonomi baru yang mencari bahan-bahan tambahan dalam menciptakan konflik; modal sosial itu dapat habis tergerus, jika tak dirawat. Dalam tekanan seperti itu, potensi agama dapat berubah-dari modal sosial untuk perdamaian menjadi potensi 
konflik. Meskipun agama tak menjadi sumber sebuah konflik, kini ada kekhawatiran bahwa dalam situasi yang terus rawan, agama dapat menjadi sumber konflik baru. Sebelum situasinya demikian memburuk, modal sosial adat dan agama ini perlu diremajakan kembali.20

\section{c. Indonesia: Melampaui kategori agama}

Point terakhir ini mengingatkan kita akan pentingnya melakukan analisis yang melampaui kategori agama, bahkan dalam konflik-konflik agama. Di Indonesia yang, menurut Konstitusi, mencita-citakan suatu masyarakat dimana agama-agama dapat hidup berdampingan dan berperan secara konstruktif, kesetiaan utama kelompok-kelompok agama tak berhenti pada agamanya sendiri. Solidaritas pun lebih mudah dibangun di antara kelompok lintas agama yang memiliki aspirasi keindonesiaan yang sama. Dalam kaitan ini, kita patut berbangga bahwa dalam setiap konflik biasanya yang ada bukan hanya berita sedih tapi juga berita gembira tentang kuatnya semangat pembelaan terhadap kehidupan bersama yang melampaui kelompok masing-masing. Pernyataan yang dengan segera dikeluarkan oleh organisasi-organisasi masyarakat Kristen dan Muslim arus utama menunjukkan hal itu. Persekutuan Gereja-gereja Indonesia (PGI), memulai pernyataannya dengan menyesalkan peristiwa yang telah menodai kekhusukan dan kegembiraan umat Muslim dalam merayakan Idul Fitri, serta mengecam dengan keras pembubaran Sholat Ied dan pembakaran mesjid. Sementara itu, Majelis Ulama Indonesia (MUI) Provinsi Papua "Menyerukan kepada umat Islam di seluruh Indonesia untuk tidak menjadikan peristiwa kekerasan Tolikara ini sebagai alasan untuk melahirkan kekerasan-kekerasan baru, atas nama "jihad"." Sebagai contoh misalnya, masyarakat Papua-apapun agamanyadengan segala keterbatasannya, dengan segala kesulitannya, dan perlakuan yang buruk selama puluhan tahun, telah kerap diuji dengan persoalan-persoalan sulit semacam ini. Sementara masyarakat memperkuat dirinya dengan aliansi-aliansi dan ide-ide yang melampaui batas-batas agamanya, kerap kali yang disesalkan adalah pemerintah pusat dan daerah yang salah langkah atau bahkan memperburuk situasi, dan tindakan aparat keamanan yang represif secara tak terukur. Yang terakhir ini tampak jelas dalam penanganan kasus Tolikara.

Kembali ke kasus konflik/kekerasan sosial yang berbasis agama, sumbangan terkecil adalah tidak memperburuk situasi dengan menjadikan berbagai kasus tersebut sebagai bahan provokasi. Yang

20 Seperti disampaikan Dr. Idrus Alhamid, Ketua STAIN Al-Fattah Jayapura (dalam disertasinya di UGM, 2014), 
diperlukan adalah arus informasi yang positif, bukan yang membakar. Khususnya untuk kita, baik Muslim ataupun Kristen, klaim-klaim keagamaan yang dibangkitkan dengan menjadikan kasus Tolikara sebagai pembenaran mungkin hanya bermanfaat untuk kepentingan kelompok sendiri, bukan untuk kepentingan saudara-saudara kita di daerah terjadinya konflik.

\section{Resolusi Harmonisasi Antar Umat Beragama}

Gusdur pernah mengatakan bahwa konflik berlatarbelakang apapun adalah sebuah upaya dalam mendewasakan manusia. Bahawasanya dengan konflik maka manusia akan saling memahami persoalan lebih detail suatu persoalan yang sesunggunya, sehingga ketika konflik tersebut terlahir untuk berikutnya maka masyarakat sudah kritis dan tentu tidak mengedepankan emosional dalam menyelesaikannya.

Selain terbentuknya pola pendewasaan, kalimat atau pernyataan Gus Dur diatas dapat dipahami bahwa sebenarnya agama dapat memberi sumbangsih positif bagi masyarakat dengan memupuk persaudaraan dan semangat kerjasama antar anggota masyarakat. Namun sisi yang lain, agama juga dapat sebagai pemicu konflik antar masyarakat beragama. Ini adalah sisi negatif dari agama dalam mempengaruhi masyarakat Dan hal ini telah terjadi di beberapa tempat di Indonesia. Mengantisipasi terjadinya konflik/kekerasan sosial antar masyarakat beragama khususnya yang terjadi di Indonesia, maka formulasi harmonisasi antar umat beragama dapat dilakukan dengan pola sebagai berikut.

\section{a. Menyatukan Perbedaan dan Sikap}

Perlu disadari bahwa faktor kekerasan agama tidak hanya dipicu oleh faktor eksternal seperti kepentingan politik, ekonomi dan sosial. Faktor internal juga dapat memberikan kontribusi yang besar. Masalah interpretasi atau penafsiran merupakan salah satu masalah utama yang bisa mendorong umat beragama melakukan tindak kekerasan. Di dalam sejarah kekristenan banyak tindakan kekerasan yang dilakukan oleh gereja karena kesalahan dalam melakukan penafsiran terhadap Kitab Suci. Orang-orang yang tekstualis memahami apa yang tertulis di dalam Alkitab secara literal dan menerapkannya di dalam konteks yang berbeda. Proses eksegese yang sebenarnya diabaikan sehingga mereka gagal untuk mendapatkan makna dari apa yang tertulis dan memusatkan perhatian terhadap teks secara mentah tanpa melakukan penggalian apapun. Hal itu pun sama terjadi terhadap agama Islam, khususnya di Indonesia. ${ }^{21}$

${ }^{21}$ Berdasarkan survei yang dilakukan, perilaku kekerasan agama di Indonesia berkorelasi positif dengan pemahaman agama yang tekstual. Ajaran-ajaran agama tentang kekerasan baik itu 
Berdasarkan hal di atas, tidak dapat dipungkiri bahwa agama merupakan sumber identitas yang sangat kuat dalam diri seseorang. Agama profetik seperti Islam dan Kristen, cenderung melakukan kekerasan segera setelah identitas mereka terancam. Persaingan antar agama yang memicu konflik sangat mudah terjadi apabila salah satu kelompok merasa identitasnya terancam. Misalkan bisa kita lihat pada konflik Ambon dan Poso jika dalam konteks dalam negeri. Potensi ini menjadi semakin besar ketika para pemimpin politik berusaha mengkonstruksi identitas negara berdasarkan agama tertentu yang mayoritas. Di satu sisi itu bisa menimbulkan arogansi dari kelompok pemeluk agama yang mayoritas dan perasaan terancam dan terintimidasi yang dirasakan oleh kelompok minoritas.

Namun demikian, sejarah kekristenan telah membuktikan bahwa semakin dekat gereja secara institusi dengan politik pemerintahan semakin bobrok kondisi keagamaannya. Usaha-usaha untuk mebentuk negara Kristen telah dilakukan dan terbukti gagal. Calvin mencoba menciptakan sebuah kota yang ilahi di Geneva dan tidak berhasil. Demikian juga pada abad ke-4 ketika Konstantinus bertobat dan menyatukan gereja dengan negara, pada akhirnya itu pun mengalami kegagalan baik di dalam sisi pemerintah maupun gereja itu sendiri. Gereja pada akhirnya terlibat secara aktif dalam tindak kekerasan yang imoral dan melawan ajaran dari agamanya sendiri. ${ }^{22}$ Di Indonesia pada saat ini kita sedang berhadapan dengan gerakan Islam fundamentalis yang berusaha untuk mendirikan negara Islam. Sudah terbukti bahwa itu merupakan salah satu sumber terbesar kekerasan agama yang terjadi di negara kita. Bukan hanya gereja atau kelompok agama lain yang dianggap sebagai musuh melainkan juga kelompok Islam lainnya yang tidak setuju dengan ide negara Islam tersebut. Akibatnya negara kita

berasal dari Alqur'an, seperti kebolehan suami memukul istri bila ia mangkir dari kewajibannya (Q.S. 4: 34-35), maupun Sunnah seperti hadis yang menyatakan anak perlu diperintahkan salat ketika berumur tujuh tahun, dan boleh dipukul (bila tidak salat) ketika berumur sepuluh, adalah sedikit contoh dari ajaran Islam tentang perlunya kekerasan. Survei menunjukkan bahwa orang yang bersedia merusak gereja yang tidak memiliki izin berjumlah 14,7\%, mengusir kelompok Ahmadiyah $28,7 \%$, merajam orang berzina $23,2 \%$, perang melawan non-muslim yang mengancam $43,5 \%$, menyerang atau merusak tempat penjualan minuman keras $38,4 \%$, mengancam orang yang dianggap menghina Islam 40,7\%, jihad di Afghanistan dan Irak 23,1\%, dan jihad di Ambon dan Poso $25,2 \%$. Sementara untuk bentuk tindakan kekerasan yang bersifat domestik, diperoleh tingkat kesediaan berikut: mencubit anak agar patuh pada orangtua $22 \%$, memukul anak di atas sepuluh tahun agar salat 40,7\%, suami memukul istri jika tidak melakukan kewajibannya 16,3\%.

22 John L. Esposito dan Dalia Mogahed, Saatnya Muslim Bicara, (Bandung: Mizan, 2008), h. 28-31. Dalam realitas negara kita sekarang ini, terorisme adalah bentuk paling nyata dari kekerasan politik-agama di Indonesia. Dalam konteks teologis, terorisme bisa mengambil bentuknya dari agama sebagai landasan dan alat untuk mendapatkan kekuasaan, sebagai tujuan dari teror tersebut. Inilah analogi gambaran situasi tragis kehidupan. 
mengalami penderitaan yang sangat dalam. Muncul kecurigaan antara pemeluk agama dan memicu terbentuknya semangat separatis.

\section{b. Membangun Struktur Pemahaman Keberagamaan}

Gagasan-gagasan yang diontarkan oleh para pemikir di bidang keagamaan dan para ahli perbandingan agama untuk merukunkan antarkelompok pemeluk agama dapat dirangkum sebagai berikut. Pertama, dengan jalan sinkretisme. Paham ini berkeyakinman bahwa pada dasarnya semua agama itu adalah sama. Sinkretisme berpendapat bahwa semua tindak laku harus dilihat sebagai wujud dari manifestasi dan keberadaan Asli (zat), sebagai pancaran dari Terang Asli yang satu, sebagai ungkapan dari substansi yang satu, dan sebagai ombak dari Samudra yang satu. Aliran sinkretisme ini disebut pula pan-theisme, pan-kosmisme, universlisme, atau theopanisme. Maksud dari istilahistilah ini adalah bahwa semua (pan) adalah Tuhan dan semua (pan) adalah alam (kosmos). Salah seorang juru bicara sinikretisme yang terkenal di Asia adalah S. Radhaknishnan, seorang ahli pikir India. Jalan sinkretisme yang ditawarkan di atas, menurut Profesor Mukti Ali, tidak dapat diterima sebab menurut konsepsi ajaran Islam, misalnya, Khalik (Sang Pencipta) adalah sama sekali berbeda dengan makhluk (yang diciptakan). Antara Khalik dan makhluk harus ada garis batas pemisah, sehingga dengan demikian menjadi jelas siapa yang disembah dan untuk siapa orang itu berbakti dan mengabdi.

Kedua, dengan jalan rekonsepsi. Pandangan ini menawarkan pemikiran bahwa orang harus menyelami secara mendalam dan meninjau kembali ajaran-ajaran agamanya sendiri dalam rangka konfrontasinya dengan agama-agama lain. Dengan demikian, kelak akan muncul suatu agama yang mengandung unsur-unsur dari berbagai agama. Misalnya, kandungan itu bisa berupa ajaran kasih sayang dari agama Kristen, pengertian tentang kemuliaan Allah dari agama Islam, perikemanusiaan dari ajaran Kong $\mathrm{Hu} \mathrm{Cu}$ dan perenungan dari agama Hindu. Paham ini menekankan bahwa orang harus tetap menganut agamanya sendiri, akan tetapi ia harus memasukkan unsur-unsur dari agama-agama lain. Cara kedua ini pun tidak bisa diterima karena dengan menempuh cara itu agama tak ubahnya hanya merupakan produk pemikiran manusia semata. Padahal, agama secara fundamental diyakini sebagai bersumber dari wahyu Tuhan. Bukan akal pikiran yang menciptakan atau menghasilkan agama, tetapi agamalah yang memberi petunjuk dan bimbingan kepada manusia untuk menggunakan akal dan nalarnya.

Ketiga, dengan jalan sintesis, yaitu menciptakan suatu agama baru yang elemen-elemennya diambilkan dari agama- agama lain. 
Pendekatan dengan menggunakan cara sintesis ini, dalam pandangan Mukti Ali, juga tidak bisa diterima. Agama sintesis itu sendiri tidak bisa diciptakan karena setiap agama memiliki latar belakang historis masingmasing yang tidak secara mudah dapat diputuskan begitu saja. Dengan kata lain, tiap-tiap agama terikat secara kental dan kuat kepada nilainilai dan hukum-hukum sejarahnya sendiri.

Keempat, dengan jalan penggantian. Pandangan ini menyatakan bahwa agamanya sendirilah yang benar, sedang agama-agama orang lain adalah salah, seraya berupaya keras agar para pengikut agama lain itu memeluk agamanya. Ia tidak rela melihat orang memeluk agama dan kepercayaan lain yang berbeda dengan agama yang dianutnya. Oleh karena itu, agama-agama orang lain tadi harus diganti dengan agama yang ia peluk. Dengan jalan ini, ia menduga bahwa kerukunan hidup antarumat beragama dapat dicipta dan dikembangkan. Akan halnya cara keempat ini, cara-cara penggantian sudah pasti tidak akan menimbulkan kerukunan hidup antarumat beragama, tetapi sebaliknya justu intoleransi dan ketidakrukunan yang akan terjadi. Karena caracara tersebut akan mendorong seseorang atau sekelompok orang berupaya keras dengan segala cara (entah cara yang baik atau yang tidak baik) untuk menarik orang-orang lain menganut agama yang ia peluk.

Kelima, dengan jalan atau pendekatan setuju dalam perbedaan (agree in disagreement). Gagasan ini menekankan bahwa agama yang ia peluk itulah agama yang baik. Walaupun demikian, ia mengakui antara agama yang satu dengan agama-agama lainnya selain terdapat perbedaan-perbedaan juga terdapat persamaan-persamaan. Pengakuan seperti ini akan membawa kepada suatu pengertian yang baik yang dapat menimbulkan adanya saling menghargai dan saling menghormati antara kelompok-kelompok pemeluk agama yang satu dengan kelompok-kelompok pemeluk agama yang lain. ${ }^{23}$

Dalam visi Mukti Ali, pendekatan yang kelima inilah yang tepat dan cocok untuk dikembangkan dalam membina dan mengembangkan toleransi, harmoni dan kerukunan hidup antarumat beragama, terutama di Indonesia yang terkenal sebagai masyarakat majemuk. Setiap pemeluk agama hendaknya meyakini seutuhnya dan mempercayai sepenuhnya kebenaran agama yang dipeluknya. Sikap demikian adalah sikap yang wajar dan logis. Kalau ia tidak meyakini dan mempercayai kebenaran agama yang dipeluknya, ia telah berbuat "bodoh" terhadap

${ }^{23}$ M. Dahlan Al Barry, dalam Dalam Arianti Youli Blog. "Peran dan Fungsi Agama dalam Masyarakat,"http:/ / ariantiyoulie.blogspot.com/2013/11/peran-dan-fungsi-agama-dalammasyarakat.html, diunduh pada 14-08-2015. 
agama yang dianutnya itu. Keyakinan akan kebenaran agama yang dipeluknya ini tidak membuatnya bersikap ekslusif, akan tetapi justru mengakui adanya perbedaan-perbedaan agama yang dianut orang lain di samping -tentu saja- menyadari adanya persamaan-persamaan dengan agama yang dipeluk penganut agama lain terutama yang berkaitan dengan ajaran kemasyarakatan. Sikap seperti ini akan rnembawa kepada terciptanya sikap "setuju dalam perbedaan" yang sangat diperlukan untuk membina dan mengembangkan toleransi dan kerukunan hidup antarumat beragama di Indonesia.

\section{Resolusi Kebijakan Pembangunan Agama}

Indonesia dikenal sebagai suatu sosok masyarakat yang pluralistik yang menyimpan berbagai warna dan panorama kemajemukan dan keberagaman dalam hal agama, tradisi, kesenian, kebudayaan, cara hidup dan pandangan nilai yang dianut oleh kelompok-kelompok etnis dalam masyarakat Indonesia. Pada suatu sisi, keberagaman dan kemajemukan ini bagi bangsa Indonesia bisa menjadi sebuah kekuatan yang positif dan konstruktif apabila diarahkan secara positif dan konstruktif pula. Sebaliknya, pada sisi lain, keberagaman dan kemajemukan ini bagi bangsa Indonesia akan menjadi sebuah kekuatan yang negatif dan destruktif apabila tidak diarahkan secara positif. Situasi semacam ini sangat disadari oleh Para Pendiri (founding fathers) Republik ini. Itulah sebabnya, Para Pendiri Republik ini -setelah melalui perdebatan konstitusional yang panjang- tidak mendirikan negara Indonesia menjadi negara agama, tetapi sepakat memilih dan menetapkan Pancasila sebagai dasar negara. Dengan demikian, Indonesia dalam perjalanan sejarahnya terkenal sebagai "negara Pancasila." Ia bukan negara sekuler dan bukan pula negara teokratis.

Sejauh menyangkut agama, negara telah meletakkan dasar-dasar konstitusional yang kuat dengan memberikan jaminan dan kebebasan kepada setiap penduduk dan setiap kelompok pemeluk agama untuk menjalankan akidah dan ibadat agamanya menurut keyakinan dan kepercayaannya masing-masing. Tak ada pembatasan dan pengekangan terhadap setiap warga negara untuk melaksanakan doktrin akidah dan ibadat agamanya masing- masing karena kebebasan agama merupakan hak asasi yang sangat fundamental bagi setiap warga negara di republik ini. Negara benar-benar memberikan kebebasan berakidah, beribadat dan beragama sesuai agama yang dipeluk oleh setiap warga negara.

\section{Resolusi ekspektasi Konflik/kekerasan Sosial Berlatar Agama}

Berbagai bentuk konflik yang terjadi dan terurai pada pembahasan sebelumnya, disadari mengakibatkan munculnya serangkaian gangguan terhadap kerukunan dan keharmonisan yang sebelumnya berlangsung dengan baik. Konflik-konflik ini dapat disebut misalnya konflik Aceh 
Singkil, Tolikara, Gereja Yasmin Bandung, Konflik Tanjung Balai, dan serentetan konflik sosial lainnya, pada akhirnya menyeret nama Agama. Konflik-konflik ini pada awalnya lebih disebabkan oleh faktor sosial ekonomi, tetapi dalam perkembangan selanjutnya kelompok-kelompok masyarakat tadi menggunakan isu agama sebagai label atau simbol untuk memperkuat solidaritas kelompok. Dengan kata lain, mereka menggunakan sensitivitas agama dalam rangka menyulut emosi massa untuk menggalang dan memperkuat solidaritas kelompok. ${ }^{24}$

Konflik antar etnis ini dalam perkembangannya menggunakan simbol, label dan sensitivitas agama untuk memperkuat solidaritas kelompok yang menyebabkan kedua belah pihak semakin agresif dan brutal. Konflik ini diwarnai dengan pembakaran rumah-rumah ibadat oleh kedua belah pihak, suatu hal yang sangat tidak terpuji dipandang dari sudut moral, etika, hukum, HAM dan agama. Karena simbol, label dan sensitivitas keagamaan telah dipakai, maka solidaritas dan agresivitas kelompok semakin mengeras dan meluas dengan diwarnai brutalitas yang semakin menggelegar. Keadaan demikian mendorong Pasukan Laskar Jihad Ahlussunnah Waljama'ah (Islam) yang jauh bermarkas di Jawa mengambil bagian aktif dalam konflik di Ambon ini. Jauh sebelum itu, Presiden Abdurrahman Wahid juga menyerukan kepada aparat keamanan agar mencegah Laskar Jihad untuk memasuki Ambon dan Presiden meminta kepada aparat untuk menangkap mereka jika diketahui mereka membawa senjata tajam saat hendak memasuki Ambon itu. Sudah pasti konflik Ambon yang telah berlangsung selama dua tahun ini, sebagaimana konflik-konflik lain, telah menimbulkan gangguan sangat serius terhadap sendi-sendi kerukunan sosial dan tatanan kerukunan antarumat beragama di Tanah Air. Menaruh perhatian secara serius terhadap persoalan ini, Menteri Agama Muhammad Tolchah Hasan beberapa bulan lalu telah mengambil inisiatif dengan mengundang tokoh-tokoh Muslim dan Krsiten Ambon datang dan bertemu di Jakarta untuk mendiskusikan cara-cara bagaimana mengakhiri konflik. Pertemuan tersebut menghasilkan seruan dan kesepakatan antara mereka untuk segera menghentikan konflik di

24 Sentimen-sentimen etnisitas juga ikut mempertajam dan menyumbang dalam memperbesar eskalasi konflik. Ringkas kata, konflik-konflik ini lantas berdimensi sangat kompleks dan bermotif SARA (suku, agama, ras dan antar golongan). Konflik-konflik sosial dan antaretnis lainnya terjadi di Pontianak, Aceh dan beberapa tempat lain yang menambah deretan konflik yang terjadi di Tanah Air akhir-akhir ini. Ambil saja konflik Ambon yang meletus pada awal Januari 1999 sebagai contoh. Dari penelitian para pakar, salah satu penyebab kasus Ambon bermula dari masalah kesenjangan sosial ekonomi. Orang-orang pendatang (etnis Bugis, Buton dan Makassar, BBM), yang beragama Islam dan dikenal sebagai para pekerja keras dan sukses, menikmati taraf kehidupan dan ekonomi yang jauh lebih baik daripada penduduk Ambon yang mayoritas beragama Kristen. Jalaluddin Rakhmat, Benarkah Agaman Menyebabkan Tindakan Kekerasan? dalam Maarif ol.6. No. 1-April 2011, h.167 
Ambon. Namun massa di tingkat akar rumput masih tetap terlibat dalam konflik sehingga seruan dan kesepakatan antara tokoh-tokoh Kristen dan Muslim itu tidak mempunyai efek sebagaimana yang mereka harapkan bersama. Karena situasi konflik belum menunjukkan adanya tanda- tanda mereda, maka beberapa waktu yang lalu pemerintah telah memberlakukan keadaan darurat sipil dengan tujuan untuk segera menanggulangi konflik di Ambon dan Maluku Utara ini. Hasilnya cukup positif. Konflik di daerah tersebut dapat diredam sehingga keadaannya dapat dikendalikan, walaupun kadang-kadang riak-riak konflik dalam skala kecil masih juga terjadi. Bagaimana pun, konflik Ambon dan Maluku Utara ini (dan konflikkonflik di daerah- daerah lain) hendaknya bisa dicari solusinya agar rekonsiliasi antara pihak-pihak yang terlibat konflik bisa segera dicapai sehingga tatanan kehidupan dan ketertiban dapat berjalan normal kembali dan begitu pula format administrasi serta roda pemerintahan setempat dapat berjalan secara normal dan berfungsi kembali sebagaimana mestinya. Dengan demikian, pilar- pilar kerukunan sosial, kerukunan antar umat beragama dan kerukunan nasional dapat dibangun kembali secara kukuh dan kuat yang pada gilirannya akan memperkuat pula sendi-sendi integrasi nasional. Dengan demikian pula, malapetaka besar yang akan menimpa bangsa ini yang berupa disintegrasi bangsa dan disintegrasi nasional dapat dicegah dan dihindari.

Semua kelompok umat beragama yang ada di Indonesia, tanpa kecuali, hendaknya secara arif mengambil hikmah dan pelajaran berharga dari konflik-konflik yang destruktif ini. Sikap ekslusif, intoleran, mau menang sendiri, penafsiran parsial dan tidak proporsional terhadap teksteks kitab suci, serta klaim-klaim kebenaran secara berlebih-lebihan terhadap doktrin dan teologi agama yang dianut oleh suatu komunitas agama hendaknya ditinggalkan. Sebaliknya, semangat "sepakat dalam ketidaksepakatan" (agree in disagreement), sikap inklusif, pluralis, humanis, arif, bijak dan toleran sudah seharusnya lebih dikedepankan dalam rangka membangun dan mengembangkan toleransi, keharmonisan dan kerukunan antarumat beragama yang lebih kodusif dan lebih sejuk dan menyejukkan di Tanah Air ini.

\section{Penutup}

Segala bentuk kekerasan sosial atas nama agama merupakan suatu hal yang tidak bisa diterima oleh pihak manapun. Karena jika kita melihat pada bentuk dan substansi agama, maka tidak ada satupun agama di dunia ini yang mengajarkan manusia untuk berbuat anarki dan kekerasan terhadap manusia lainnya. Terlebih-lebih jika perbuatan kekerasan tersebut dilakukan atas nama suatu agama tertentu. Justru sebaliknya, semua agama di dunia ini mengajarkan 
kasih sayang, toleransi, cinta damai, saling mengasihi antar sesama manusia lainnya. Sehingga secara otomatis segala bentuk tindakan kekerasan dilarang oleh semua agama.

Kendatipun Indonesia memiliki jumlah penduduk yang hampir $90 \%$, beragama Islam, namun Indonesia bukanlah sebuah negara Islam layaknya Saudi Arabia. Indonesia adalah negara demokrasi yang di dalam makna Pancasilanya mengakui pluralisme baik suku, ras, warna, maupun agama. Slogan yang sangat terkenal berkaitan dengan hal ini adalah "Bhinneka Tunggal Ika". Tetapi, melihat dari fakta dan kenyataan, menjadi warganegara Indonesia dan beragama Muslim terasa sedikit 'menggerahkan' dan 'memalukan'. Indonesia saat ini tengah dikenal dunia dengan berbagai isu-isu kekerasannya. Di antaranya yang paling 'mempopularkan' nama Indonesia di mata dunia adalah isu kekerasan berbasis agamanya, di mana sebagian besarnya dilakukan oleh beberapa oknum pemeluk agama Islam di Indonesia.

Sebenarnya, kekerasan berbasis agama sudah ada sejak berabad-abad lalu. Kekerasan agama selama berabad-abad merupakan kejahatan terburuk yang telah mengisi peradaban manusia. Sesuatu yang paradoks, karena agama mengajarkan nilai-nilai luhur, tetapi agama juga bertanggung jawab terhadap terjadinya kerusakan di muka bumi ini. Dalam editorial bukunya, "Violence and the Sacred in the Modern World", Mark Juergensmeyer menyatakan: Violence has always been endemic to religion. Images of destruction and death are envoked by some of religion's most popular symbols, and religious wars have left through history a trail of blood. The savage martyrdom of Hussain in Shiite Islam, the crucifixion of Jesus in Christianity, the sacrifice of Guru Tegh Bahadur in Sikhism, the bloody conquest in the Hebrew Bible, the terrible battles in the Hindu epics, and the religious wars attested to in Sinhalese Buddhist chronicles indicate that in virtually every tradition images of violence occupy as central a place as portrayals of non-violence.

Bila dikaji lebih mendalam, maka format kekerasan sosial yang berlatar belakang agama, sebenarnya disebabkan oleh sentimen dan fanatisme keagamaan yang berlebihan. Sentimen dan fanatisme keagamaan inilah yang banyak memberi andil atas terciptanya setiap adegan kerusuhan dan terjadinya kekerasan sosial. Seyogyanya, kekerasan sosial berbasis agama tidak mengaburkan tujuan agama tersebut. Charles Caleb Colton (1825) dalam Pencarian Manusia Akan Allah, ia mengatakan: "Manusia akan bergumul demi agama, menulis demi itu, bertempur demi itu, mati demi itu, berbuat apa saja kecuali hidup demi itu. Apabila agama yang sejati mencegah satu kejahatan, agama-agama palsu membuat dalih untuk ribuan kejahatan". ${ }^{25}$ Hal ini diamini pula oleh Dr. Hamim Ilyas (2007), dengan mengatakan: “agama menjadi keras

25 Emile Durkheim, The Elementary Forms of the Religious Life, (London: George Allen \& Unwin, t.th), h.10. 
lantaran adanya suatu tradisi interpretasi sosio-religius (mazhab) yang menjadikan doktrin sebagai sutatu pembenaran bertindak dengan mengembangkan dokrin-doktrin ideologis". ${ }^{26}$ Agama sebuah keyakinan. Bukan barang mainan. Setiap orang bersedia melakukan apa saja, demi keyakinan agama. Inilah yang harus diperhatikan oleh semua golongan, agar tidak bertindak sewenang-wenang. Karena hanya akan menyulut perang atau terjadinya kekerasan sosial antar agama. Beberapa hal yang bisa dilakukan untuk menangani konflik antar agama : Pertama, Dalam menangani konflik antar agama, jalan terbaik yang bisa dilakukan adalah saling mentautkan hati di antara umat beragama, mempererat persahabatan dengan saling mengenal lebih jauh, serta menumbuhkan kembali kesadaran bahwa setiap agama membawa misi kedamaian. Kedua, Tidak memperkenankan pengelompokan domisili dari kelompok yang sama didaerah atau wilayah yang sama secara eksklusif.

Ketiga, Masyarakat pendatang dan masyarakat atau penduduk asli juga harus berbaur atau membaur atau dibaurkan. Keempat, Segala macam bentuk ketidakadilan struktural agama harus dihilangkan atau dibuat seminim mungkin. Kelima, Kesenjangan sosial dalam hal agama harus dibuat seminim mungkin, dan sedapat-dapatnya dihapuskan sama sekali. Keenam, Perlu dikembangkan adanya identitas bersama (common identity) misalnya kebangsaan (nasionalisme-Indonesia) agar masyarakat menyadari pentingnya persatuan dalam berbangsa dan bernegara.

\section{Referensi}

Abdul A’la Al-Maududi. "Konflik Kekerasan; Antara Politisasi Agama, Etnisitas, dan Politik Kekuasaan". Paramedia, Vol. 8, No. 3, 2007.

Ahmad Zainul Hamdi," "Klaim Religious Authority dalam Konflik Sunni-Syi'i Sampang Madura", ISLAMICA. Vol. 6, No. 2, Maret 2012.

Astrid S. Susanto, Pengantar Sosiologi dan Perubahan Sosial, Jakarta: Binacipta, 1985.

Budhy Munawar Rachman, Membela Kebebasan Beragama, Jakarta: LSAF dan Paramadina, 2002.

Emile Durkheim, The Elementary Forms of the Religious Life, London: George Allen \& Unwin, t.th.

Handoko, Imam Priyo, “Upaya Menjadikan Dunia Lebih Indah", Kompas. Rabu 15 Februari 2006.

Ihsan Ali Fauzi, et al., Laporan Penelitian Pola-pola Konflik Keagamaan di Indonesia (1990-2008), Jakarta: Yayasan Wakaf Paramadina (YWP), Magister Perdamaian dan Resolusi Konflik, Universitas Gadjah Mada (MPRKUGM), The Asia Foundation (TAF), 2009.

Jacques Bertrand, Nationalism and Ethnic Conflict in Indonesia, Cambridge: Cambridge University Press, 2004. 
Jajang Jahroni, Tekstualisme, Islamisme dan Kekerasan, dalam: Islamlib.com, 07 Agustus 2008.

Jalaluddin Rakhmat, Benarkah Agama Menyebabkan Tindakan Kekerasan? dalam Maarif Vol.6. No. 1-April 2011.

John L. Esposito dan Dalia Mogahed, Saatnya Muslim Bicara, Bandung: Mizan, 2008.

Karen Amstrong, Berperang Demi Tuhan: Fundamentalisme Dalam Islam, Kristen, dan Yahudi, Bandung: Mizan, 2001.

M. Dahlan Al Barry, dalam Youli Blog. "Peran dan Fungsi Agama dalam Masyarakat,"http://ariantiyoulie.blogspot.com/2013/11/peran-danfungsi-agama-dalam-masyarakat.html, diunduh pada 14-08-2015.

Robert N. Bellah, Beyond Belief: Esei-esei Tentang Agama di Dunia Modern, Jakarta: Paramadina, 2000.

Slamet Effendy Yusuf, "Review 5 Tahun Kehidupan Umat Beragama di Indonesia: Perspektif MUI", Makalah pada Kongres FKUB di Jakarta, 21-22 November 2011.

Rizal Panggabean dan Ihsan Ali-Fauzi,Pemolisian Konflik Keagaman di Indonesia, PUSAD Paramadina dan MPRK UGM, 2014.

Tim Penyusun, Laporan Kebebasan Beragama/ Berkeyakinan dan toleransi,(Jakarta: the Wahid Institute, 2010.

Umi Sumbulah, Agama dan Kekerasa: Menelisik Akar Kekerasan dalam Studia Philosophica et Theologia, Vol. 5. No. 1 Maret 2005. 